\title{
Planned Criterion Group Composition Relationship
}

National Cancer Institute

\section{Source}

National Cancer Institute. Planned Criterion Group Composition Relationship. NCI

Thesaurus. Code C93467.

A relationship between a planned criterion group and a planned activity, planned

observation result or other planned criterion group that is a component, i.e. a relationship between a logical set of parenthesis and one of the items inside the parentheses. 